\title{
EDITORIAL
}

\section{Usando a biodiversidade com sabedoria}

Estima-se que o Brasil detenha $22 \%$ das variedades de plantas, animais terrestres e aquáticos do mundo. Desde os tempos mais remotos, esta incrível biodiversidade tem representado um fabuloso arsenal contra diversas doenças que afetam homens e animais. Até hoje, as florestas constituem a principal fonte de alimento e, portanto, a própria sobrevivência de vários povos brasileiros. Porém, a crescente devastação das mesmas promovida pelos interesses escabrosos de empresários, muitos destes incentivados pelo próprio governo, está levando a uma gradual e irreversível perda desta rica biodiversidade, sem que haja tempo para que os cientistas possam estudar suas potencialidades. Infelizmente o país tende a ignorar esta riqueza, pois cerca de mil espécies são extintas a cada ano (três por dia).

A água é um dos aspectos mais importantes para a preservação da biodiversidade. Apesar de 3/4 do planeta ser composto de água, a humanidade tem acesso apenas a uma pequena fração renovável dela, pois $97 \%$ são águas salgadas e uma parte está congelada nos pólos. Outros problemas como: assoreamento dos rios e lagoas; contaminação da água por vírus e bactérias; presença de organomercuriais e tributilestanho na cadeia trófica; uso indiscriminado de pesticidas organoclorados na agricultura; não esquecendo ainda a biopirataria crescente por falta de legislação específica que iniba esta prática são tão ou mais críticos.

Atualmente, o perigo mais real que a nossa biodiversidade tem a vista é o projeto de conversão em lei da medida provisória nº 1.855-42 (1999) que trata da reformulação do Código Florestal. Este projeto de conversão desmonta o Código Florestal atual e o transforma num salvo-conduto para a devastação. Entre inúmeros escárnio apresentados no projeto, podemos citar: redução da área de reserva legal no Cerrado de 50\% para 20\% e a redução da área de reserva legal na Amazônia de $80 \%$ para 50\%. Este projeto, que foi aprovado na comissão mista do Congresso Nacional, está sendo apoiado integralmente pela chamada "bancada ruralista".

Apesar do quadro negro traçado existem ações importantes que podem ser implementadas a fim de proteger nossa biodiversidade, como por exemplo: incentivo à produção de plantas e animais nativos (terrestres ou aquáticos) em seus hábitats naturais, preservando desta forma a floresta (ex. açaí e o peixe-boi); melhoramento da qualidade genética dos nosso rebanho para que se produza mais, em áreas menores; evitar o contrabando da nossa biodiversidade; apoio ao projeto de lei da senadora Marina Silva (PT/AC) que diz que "as comunidades indígenas serão os titulares dos conhecimentos tradicionais e os recursos genéticos passam a ser bens da união"; aparelhar cientificamente a Polícia Federal, principalmente na Amazônia, para que essa entidade entenda que o contrabando e o narcotráfico são tão ruins para o país como é o biocontrabando; destinar recursos, bolsas de estudo (mestrado e doutorado), bolsa de fixação de recém-doutor do CNPq, FINEP, além de recursos do fundo do petróleo para desenvolvimento e a produção de fitoterápicos e animais nativos, economicamente viáveis, com controle de qualidade.

Ao chegar próximo do novo milênio, o país não pode ficar observando em "berço esplêndido" este ato de insanidade. 